\title{
Loss of Inhibitory Neuron AMPA Receptors Contributes to Ataxia and Epilepsy in Stargazer Mice
}

\author{
Karen Menuz ${ }^{1}$ and Roger A. Nicoll ${ }^{1,2}$ \\ Departments of ${ }^{1}$ Cellular and Molecular Pharmacology and ${ }^{2}$ Physiology, University of California, San Francisco, San Francisco, California 94143
}

\begin{abstract}
Stargazer mice are characterized by ataxia and seizures, which resemble the human disorder absence epilepsy. Stargazin, the protein mutated in stargazer mice, promotes the expression and function of neuronal AMPA receptors (AMPARs). However, it is unclear how decreased expression of excitatory AMPARs generates stargazer seizures, given that seizures often result from increased neuronal excitability. Additionally, although stargazer ataxia has been attributed to loss of AMPARs from cerebellar granule cells, other cerebellar neurons have not been examined. To examine the role of AMPAR dysfunction in these behavioral phenotypes, electrophysiological recordings were used to probe AMPAR regulation in relevant brain regions. We found that both cerebellar Purkinje cells and inhibitory thalamic reticular nucleus neurons have strongly reduced synaptic AMPAR function in stargazer mice. Together, our data suggest that impaired AMPAR regulation in multiple neuron populations may contribute to the behavioral phenotypes of absence seizures and ataxia seen in stargazer mice and imply that an understanding of human genetic disorders will require knowledge of both the genes that are mutated as well as their precise cellular expression pattern.
\end{abstract}

Key words: epilepsy; seizure; stargazin; thalamus; AMPAR; ataxia

\section{Introduction}

Inherited forms of epilepsy, both in humans and mice, have proved invaluable in understanding this complex medical disorder. A series of mice harboring mutations in calcium channel subunits, including tottering, leaner, ducky, lethargic, and stargazer, share the phenotypes of ataxia and absence seizures (Fletcher et al., 1996; Burgess et al., 1997; Letts et al., 1998; Barclay et al., 2001). Stargazin, the protein mutated in stargazer (stg) mice, is also known as $\gamma-2$ because of its homology with the $\gamma-1$ calcium channel subunit, and it can modulate calcium channel activity (Letts et al., 1998; Klugbauer et al., 2000). Calcium currents are enhanced in thalamic relay neurons of stargazer mice (Zhang et al., 2002), and this defect may initiate their absence seizures, which arise from thalamocortical abnormalities (McCormick and Contreras, 2001). In contrast, calcium currents appear unaffected in the cerebellum of stargazer mice (Chen et al., 2000), a brain region associated with ataxia.

Recent work attributes stargazer ataxia to the nearly complete loss of AMPA receptors (AMPARs) from cerebellar granule cells, because of the role of stargazin as an AMPAR auxiliary subunit that regulates receptor trafficking, gating, and pharmacology (Milstein and Nicoll, 2008). Related family members known as

\footnotetext{
Received June 15, 2008; revised Aug. 28, 2008; accepted Aug. 30, 2008

This work was supported by grants from the National Institutes of Health (R.A.N.) and L'Oreal-United Nations Educational, Scientific, and Cultural Organization and Epilepsy Foundation predoctoral fellowships (K.M.). We thank Dr. 0. Olsen for assistance with immunohistochemistry and J. O'Brien, P. Apostolides, and K. Bjorgan for technical support. We also appreciate critical comments by Dr. A. Tzingounis on this manuscript.

Correspondence should be addressed to Roger A. Nicoll, Department of Cellular and Molecular Pharmacology, University of California, San Francisco, Genentech Hall, N272D, 600 16th Street, San Francisco, CA 94143. E-mail: nicoll@cmp.ucsf.edu

D0I:10.1523/JNEUROSCI.2732-08.2008

Copyright $\odot 2008$ Society for Neuroscience $\quad 0270-6474 / 08 / 2810599-05 \$ 15.00 / 0$
}

transmembrane AMPAR regulatory proteins (TARPs) are also widely expressed in the CNS (Tomita et al., 2003; Fukaya et al., 2005; Lein et al., 2007). Given these recent findings, it has been questioned whether a loss of AMPARs also contributes to stargazer seizures. However, inherited forms of epilepsy often involve mutations in ion channels that lead to increased neuronal excitability (Singh et al., 1998; Wallace et al., 1998; De Fusco et al., 2000; Baulac et al., 2001), whereas the loss of excitatory AMPARs would decrease neuronal activity.

Absence seizures involve thalamic networks consisting of inhibitory nucleus reticularis (nRT) neurons and excitatory thalamocortical relay neurons (McCormick and Contreras, 2001), which both express AMPARs as well as stargazin (Fukaya et al., 2005; Lein et al., 2007). To determine whether impaired AMPAR currents might play a role in stargazer seizures, we investigated thalamic AMPAR function. We found a selective reduction of synaptic AMPARs in inhibitory nRT neurons, but not excitatory relay neurons. We went on to test whether cerebellar neurons in addition to granule cells play a role in stargazer ataxia. We found that inhibitory Purkinje cells have severely impaired synaptic, but not extrasynaptic, AMPAR function. Together, our data present a solution to the paradox of how a loss of AMPARs could produce absence seizures, and provide evidence that inhibitory neurons make a contribution to the ataxic and epileptic phenotypes of stargazer mice.

\section{Materials and Methods}

Animals. All experiments followed University of California, San Francisco Institutional Animal Care and Use Committee guidelines. Stargazer mice have been described previously (Letts et al., 1998). PCR genotyping was performed with the following primers: forward wild type (F-wt), CATTTGTTATACATGCTCTAG; reverse (R)-wt, ACTGTCACTC- 
TATCTGGAATC; F knock-out (F-KO), GAGCAAGCAGGTTTCAGGC; R-KO, ACTGTCACTCTATCTGGAATC.

Electrophysiology. Coronal slices $(300 \mu \mathrm{m})$ were prepared from young [postnatal day 14 (P14)-P19] and mature (P21-P29) mice for thalamic recordings. The recording and cutting solution contained (in $\mathrm{mM}) 126$ $\mathrm{NaCl}, 3 \mathrm{KCl}, 26 \mathrm{NaHCO}_{3}, 1.25 \mathrm{NaH}_{2} \mathrm{PO}_{4}, 20$ glucose, $1.3 \mathrm{MgCl}_{2}$, and 2.5 $\mathrm{CaCl}_{2}$. Slices were cut at $4-6^{\circ} \mathrm{C}$, incubated $30 \mathrm{~min}$ at $32-34^{\circ} \mathrm{C}$, and maintained at room temperature (RT). Parasaggital cerebellar slices $(300 \mu \mathrm{m})$ from 3- to 4-week-old mice for Purkinje cell recordings were prepared similarly except slices were cut at $0-4^{\circ} \mathrm{C}$ and incubated $15 \mathrm{~min}$ at $30-$ $34^{\circ} \mathrm{C}$. The Purkinje cell solution contained (in mM) $119 \mathrm{NaCl}, 2.5 \mathrm{KCl}$, 26.3 $\mathrm{NaHCO}_{3}, 1 \mathrm{NaH}_{2} \mathrm{PO}_{4}, 11$ glucose, $1.3 \mathrm{MgCl}_{2}$, and $2.5 \mathrm{CaCl}_{2}$.

Whole-cell recordings from visually identified thalamic neurons were obtained at RT with glass electrodes (4-6 M $\Omega$ ) using an Axopatch-1D amplifier (Molecular Devices). The pipette solution contained (in $\mathrm{mM}$ ) 110 Cs-methanesulfonate, $10 \mathrm{CsCl}, 10$ HEPES, $2 \mathrm{MgCl}_{2}, 4 \mathrm{Na}_{2}$-ATP, 0.4 $\mathrm{Na}-\mathrm{GTP}, 10$ Cs-BAPTA, 0.1 spermine, and 5 2(triethylamino)- $\mathrm{N}-(2,6-$ dimethylphenyl) acetamine (QX-314), pH 7.2-3, adjusted to 305-315 $\mathrm{mOsm}$. Thalamic neurons were identified by comparison with reference atlases, primarily the Allen Brain Atlas (Lein et al., 2007), and only slices in which the nuclei could clearly be identified were used. In some nRT recordings, $0.1 \%$ Lucifer yellow was included in the recording pipette to identify the recorded cells after double labeling fixed slices with a GAD-67 antibody (MAB5406; Millipore Bioscience Research Reagents) using standard immunohistochemistry (Olsen et al., 2007). The GAD-67 antibody selectively labeled the nRT within the thalamus, and in all cases, the recorded neurons were located within this nucleus, verifying the anatomical localization.

Thalamic neurons were held at $-70 \mathrm{mV}$, and AMPA miniature EPSCs (mEPSCs) were recorded in the presence of $500 \mathrm{~nm}$ TTX (Tocris Bioscience), $50 \mu \mathrm{M} \mathrm{D}$-APV (Tocris Bioscience), and $100 \mu \mathrm{M}$ picrotoxin (Sigma). Customized IgorPro software (Wavemetrics) was used to detect and analyze mEPSCs off line with a threshold of 8 pA. Evoked AMPAR EPSCs were first obtained at $-70 \mathrm{mV}$ in the presence of $100 \mu \mathrm{M}$ picrotoxin (Sigma). Dual-component responses were then evoked at $+40 \mathrm{mV}$, and the AMPAR current was isolated by adding $50 \mu \mathrm{M} \mathrm{D}-\mathrm{APV}$ (Tocris Bioscience). The NMDA receptor EPSC was measured by subtracting the AMPAR EPSC from the dual-component EPSC. The AMPA/NMDA EPSC ratio used the AMPAR EPSC at $-70 \mathrm{mV}$ and the NMDA receptor EPSC at $+40 \mathrm{mV}$. The rectification index was defined as $\left(I_{+40} / I_{-70}\right) \times$ $\left[\left(-70-E_{\text {rev }}\right) /\left(40-E_{\text {rev }}\right)\right]$.

Whole-cell recordings from visually identified Purkinje cells were obtained at RT using glass electrodes (1.5-3 M $\Omega$ ). The pipette solution for synaptic recordings contained (in $\mathrm{mM}$ ) 115 Cs-methanesulfonate, 20 $\mathrm{CsCl}, 10 \mathrm{HEPES}, 2.5 \mathrm{MgCl}_{2}, 4 \mathrm{Na}_{2}$-ATP, $0.4 \mathrm{Na}$-GTP, $10 \mathrm{Na}-$ phosphocreatine, 0.6 EGTA, and 0.1 spermine, and 5 QX-314, pH 7.2-3, adjusted to 305-315 mOsm. For outside-out patches, the pipette solution contained (in mM) 135 Cs-methanesulfonate, $10 \mathrm{CsCl}, 10 \mathrm{HEPES}, 2$ $\mathrm{MgCl}_{2}, 4 \mathrm{Na}_{2}$-ATP, $0.4 \mathrm{Na}-\mathrm{GTP}$, and 1 EGTA. Purkinje cells were voltage clamped at $-70 \mathrm{mV}$. Climbing fiber EPSCs were evoked by granule cell layer stimulation and were identified by their large-amplitude all-ornone response. Dual-component climbing fiber EPSCs were recorded in $10 \mu \mathrm{M}$ 1-(4-aminophenyl)-3-methylcarbamyl-4-methyl-3,4-dihydro7,8-methylenedioxy-5H-2,3-benzodiazepine (GYKI 53655; Tocris Bioscience, custom synthesis) to prevent voltage escape. Kainate receptor EPSCs were then isolated by increasing GYKI 53655 to $100 \mu \mathrm{M}$, and the difference reflected the pure AMPAR current. Parallel fiber AMPAR EPSCs were evoked by stimulation in the molecular layer, $10 \mu \mathrm{M}$ CNQX (Tocris Bioscience) was added, and metabotropic glutamate receptor (mGluR)-dependent currents were recorded by stimulating 10 times at $100 \mathrm{~Hz}$ at the same stimulation intensity (Tempia et al., 1998). For these experiments, stargazer littermates $(s t g /+$ and $+/+)$ were combined because no differences between them were observed.

Outside-out patches were pulled from Purkinje cell somas and held at $-60 \mathrm{mV}$. A Valve-Link 8 controller and pinch valves connected to a 360 $\mu \mathrm{m}$ local perfusion pipette (AutoMate Scientific) were used for rapid solution exchange. The control line contained (in $\mathrm{mM}$ ) $140 \mathrm{NaCl}, 2.4$ $\mathrm{KCl}, 10$ HEPES, 10 glucose, $4 \mathrm{CaCl}_{2}, 4 \mathrm{MgCl}_{2}, 250 \mu \mathrm{M}$ cyclothiazide (Tocris Bioscience), and $25 \mu \mathrm{M}(R S)$-CPP [(RS)-3-(2-carboxypiperazin- 4-yl)-propyl-1-phosphonic acid; Tocris Bioscience]. The test solution additionally included $10 \mathrm{~mm}$ glutamate.

Statistics. All data are given as the mean \pm SEM, and significance was determined using unpaired Student's $t$ tests. Significance was set at $p<$ 0.05 .

\section{Results}

To test whether thalamic neurons require stargazin to maintain normal AMPAR function, we compared synaptic AMPAR EPSCs in the thalamus of young wt and stg mice. We began by recording AMPAR mediated mEPSCs in nRT neurons to examine individual synapses. Both mEPSC frequency and amplitude were significantly reduced in $\mathrm{P} 14-\mathrm{P} 17$ stargazer mice (amplitude: $w t, 16.5 \pm$ $0.9 \mathrm{pA} ; \operatorname{stg}, 13.1 \pm 0.5 \mathrm{pA} ; n=10$ and 11 , respectively; $p<0.003$; frequency: wt, $1.02 \pm 0.25 \mathrm{~Hz}$ stg, $0.22 \pm 0.05 \mathrm{~Hz} ; n=9$ and 14 , respectively; $p<0.002$ ) (Fig. $1 A, B$ ). To verify the loss of AMPARs, we also measured the ratio of evoked AMPAR and NMDRA EPSCs in nRT neurons. We found that the ratio of $I_{\mathrm{AMPA}}$ measured at $-70 \mathrm{mV}$ to $\mathrm{I}_{\mathrm{NMDA}}$ measured at $+40 \mathrm{mV}$ was reduced $\sim 50 \%$ (wt, $1.19 \pm 0.09 ;$ stg, $0.67 \pm 0.14 ; n=11$ and 10 , respectively; $p<0.01$ ) (Fig. $1 C$ ). Together, the decreased mEPSC amplitude and AMPA/NMDA ratio indicate a postsynaptic loss of synaptic AMPARs. A change in AMPAR subunit composition is unlikely, given that both the mEPSC decay kinetics and the evoked AMPAR EPSC I-V relationship were unchanged (decay $\tau$ : wt, $1.91 \pm 0.22 \mathrm{~ms} ; \mathrm{stg}, 2.03 \pm 0.17 \mathrm{~ms} ; n=10$ and 11 , respectively; $p>0.05$; rectification index: wt, $0.88 \pm 0.10$; stg, $0.81 \pm$ $0.11 ; n=11$ each; $p>0.05)$.

There are several possible explanations for the lower mEPSC frequency in stargazer mice. Their decreased mEPSC size impairs detection of small amplitude mEPSCs, leading to an apparent reduction of the mEPSC frequency. However, the greatly decreased frequency in stargazer mice suggests additional changes, such as increased silent synapses or fewer total synaptic contacts, perhaps because of impaired synaptic maturation (Chen et al., 1999; Meng et al., 2006).

Given that seizures first appear in stargazer mice at $\sim$ P17-P18 (Qiao and Noebels, 1993), we predicted that the synaptic deficits should also occur in older mice. Indeed, the mEPSC amplitude was decreased in P21-P23 stargazer mice to a similar extent as in the younger mice (wt, $16.3 \pm 0.5 ;$ stg, $14.1 \pm 0.6 ; n=6$ each; $p<$ 0.02 ) (supplemental Fig. S1 $A$, available at www.jneurosci.org as supplemental material). In contrast to the younger animals, there was no significant change in the mEPSC frequency, although there was a trend toward fewer events (wt, $1.15 \pm 0.19 ;$ stg, $0.7 \pm$ $0.18 ; n=6$ each; $p>0.05$ ) (supplemental Fig. S1 $A$, available at www.jneurosci.org as supplemental material). The stronger and more consistent reduction in mEPSC frequency in younger stargazer mice may reflect delayed development of normal synaptic density and/or efficacy.

Given that stargazin is expressed throughout the thalamus (Fukaya et al., 2005; Lein et al., 2007), we also assayed the synaptic AMPAR content in excitatory relay neurons. We recorded from the lateral dorsal nucleus because of its relevance to stargazer seizures (Zhang et al., 2002). Surprisingly, mEPSCs were unimpaired in relay neurons from P14-P19 stargazer mice (amplitude: wt, $11.9 \pm 0.3 \mathrm{pA}$; stg, $12.1 \pm 0.4 \mathrm{pA} ; n=9$ and 10 , respectively; $p>0.05$; frequency: wt, $0.41 \pm 0.08 \mathrm{~Hz}$; stg, $0.38 \pm 0.06 \mathrm{~Hz} ; n=$ 9 and 10 , respectively; $p>0.05$ ) (Fig. $1 D, E)$. Likewise, the mEPSC amplitude was unchanged in P26-P29 mice (wt, $13.0 \pm$ $0.4 \mathrm{pA}$; stg, $12.0 \pm 0.3 \mathrm{pA} ; n=10$ each; $p>0.05$ ) (supplemental Fig. $S 1 B$, available at www.jneurosci.org as supplemental material), indicating that at all ages the AMPAR content at individual 
A nRT neuron
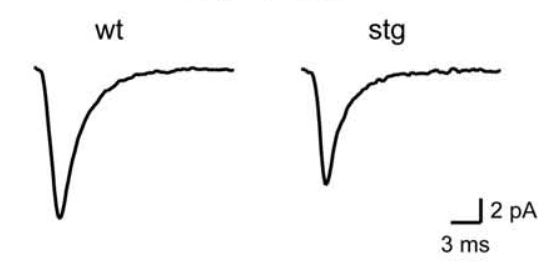

B wt

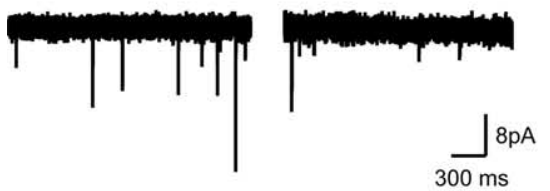

C

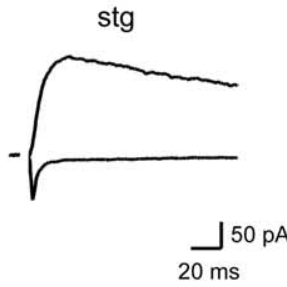

D

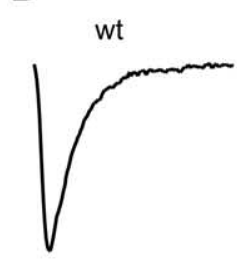

relay neuron

$\mathbf{E}$

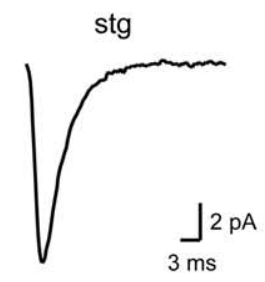

wt
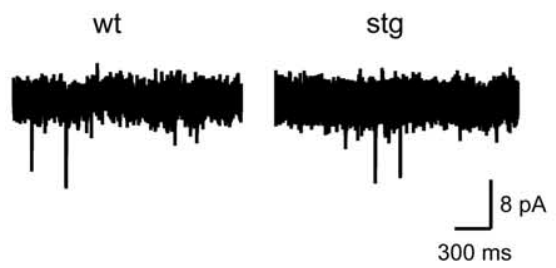
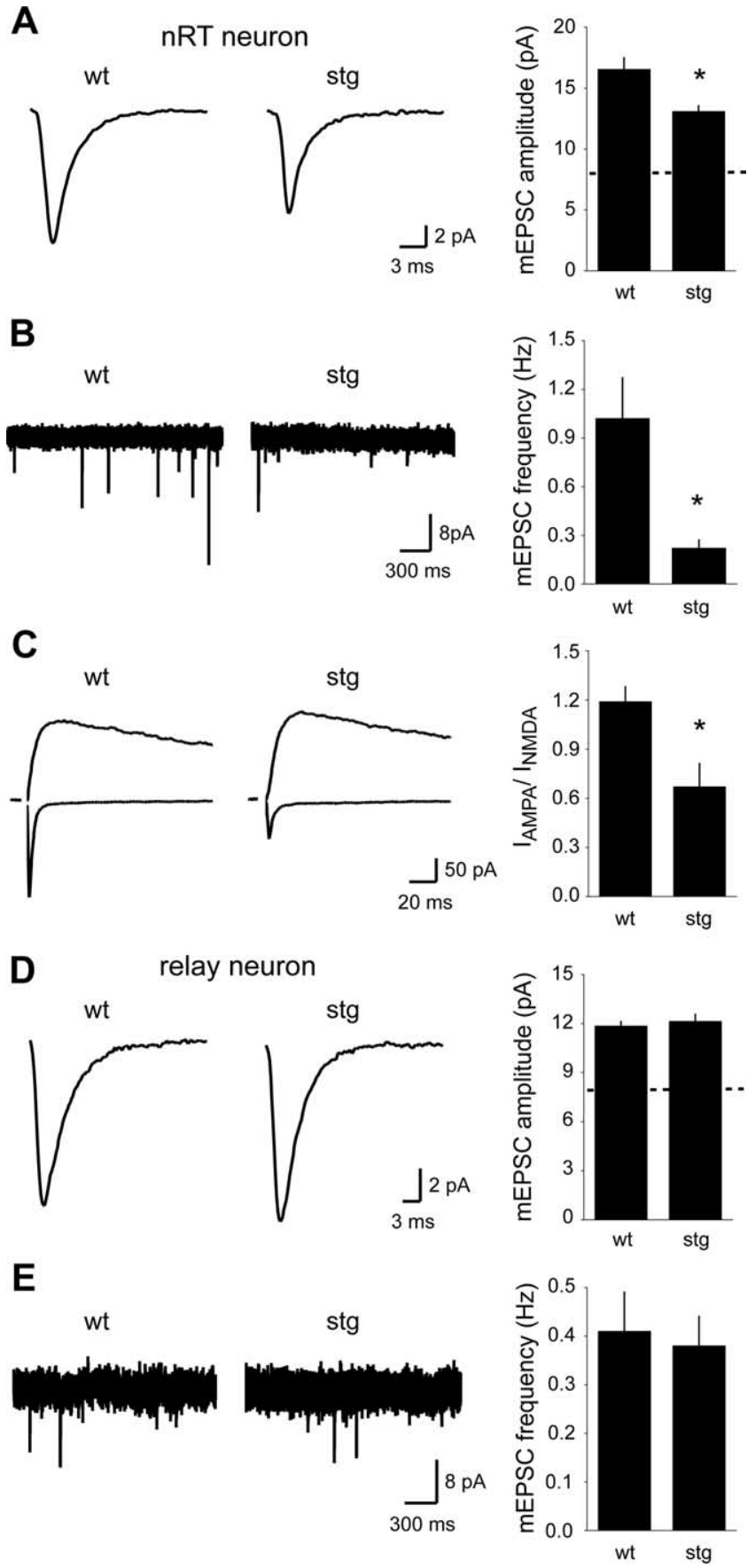

Figure 1. Synaptic AMPARs are decreased in thalamic nRT neurons, but not relay neurons, from stargazer mice. $A, B$, Both the amplitude and frequency of AMPAR $m E P S C$ s recorded from $n R T$ neurons were reduced in stargazer mice $\left({ }^{*} p<0.01\right)$. The left panels in $A$ show the averaged $\mathrm{mEPSC}$ from a representative cell of each genotype. The dashed line on the graph shows the threshold amplitude for detection. $\boldsymbol{B}$ consists of three consecutive overlaid traces that illustrate the reduced $m E P S C$ frequency. $C$, The ratio of AMPA EPSCs to NMDA EPSCS was reduced in $n R T$ neurons from stargazer mice $\left.{ }^{*} p<0.01\right) . \boldsymbol{D}, \boldsymbol{E}$, The amplitude and frequency of AMPAR $m E P S C S$ in lateral dorsal relay neurons was not different in stargazer mice compared with wild types.

relay neuron synapses is unimpaired. Unexpectedly, relay neuron mEPSC frequency was decreased in older stargazer mice (wt, $0.83 \pm 0.12 \mathrm{~Hz}$; stg, $0.43 \pm 010 \mathrm{~Hz} ; n=10$ and 11 , respectively; $p<0.02$ ) (supplemental Fig. $S 1 B$, available at www.jneurosci.org as supplemental material). Thus, there may be fewer total synapses onto mature relay neurons, which may result from impaired maturation or a secondary effect of absence seizures. To-
A
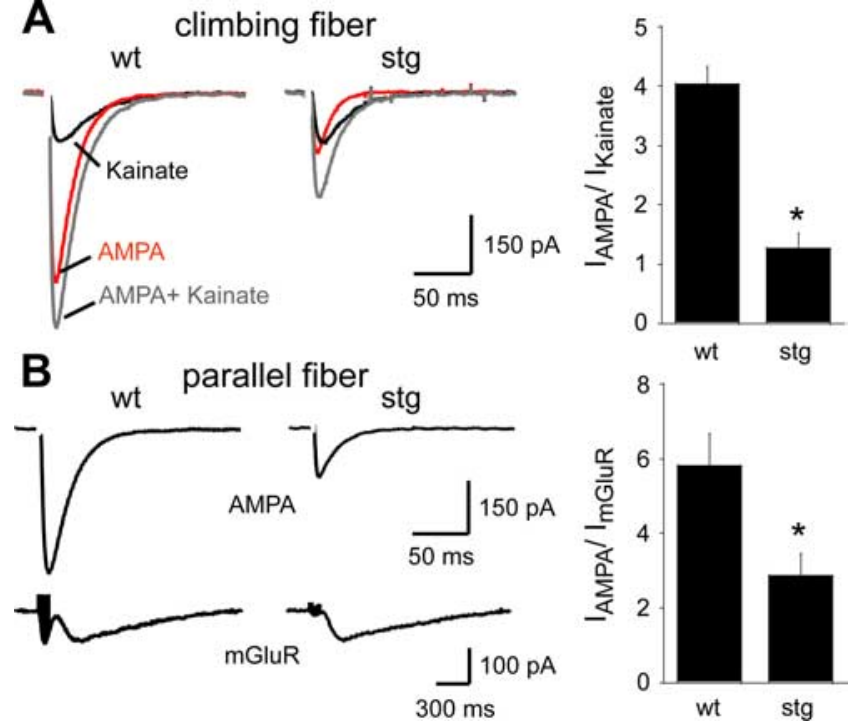

Figure 2. Decreased expression of synaptic AMPARs in Purkinje cells from stargazer mice. $A$, Dual component EPSCs (gray) were evoked in $10 \mu \mathrm{m}$ GYKI, kainate EPSCs (black) were pharmacologically isolated, and the difference was used to measure the AMPAR EPSC (red). The ratio of synaptic AMPA to kainate receptor EPSCs was smaller in stargazer mice $\left({ }^{*} p<0.001\right)$. $\boldsymbol{B}$, Similarly, the ratio of AMPAR EPSCs to mGluR-induced EPSCs at parallel fiber synapses was reduced in stargazer mice $\left({ }^{*} p<0.02\right)$.

gether, our findings indicate that loss of synaptic AMPARs occurs primarily in inhibitory nRT neurons in stargazer mice. This deficit may lead to network disinhibition and either directly or indirectly impair the finely tuned balance of thalamocortical network activity.

Our findings in nRT neurons are the first indication that stargazin regulates synaptic AMPARs in inhibitory neurons. We therefore wondered whether inhibitory neuron AMPAR also contributes to stargazer ataxia, given that most if not all cerebellar neurons express stargazin (Fukaya et al., 2005; Kato et al., 2007; Lein et al., 2007). As the sole output of the cerebellum, Purkinje cell dysfunction would contribute to ataxia. Purkinje cells are inhibitory neurons of the cerebellar cortex, but differ from most inhibitory neurons by being projection neurons rather than local interneurons. Importantly, they express stargazin and $\gamma-7$, but no other TARP family members (Fukaya et al., 2005; Lein et al., 2007).

To assay synaptic AMPAR content, we compared evoked Purkinje cell AMPAR EPSCs in stargazer mice and their littermates. We normalized the stimulation intensity between slices by comparing $I_{\mathrm{AMPA}}$ to other currents evoked by glutamate at the same synapses. At climbing fiber synapses, the ratio of $I_{\mathrm{AMPA}}$ to $I_{\text {kainate }}$ in Purkinje cells was decreased $\sim 70 \%$ (wt, $4.03 \pm 0.29 ; \mathrm{stg}, 1.28 \pm$ $0.24 ; n=7$ and 5, respectively; $p<0.001$ ) (Fig. $2 A$ ), whereas at parallel fiber synapses the ratio of $I_{\mathrm{AMPA}}$ to $I_{\mathrm{mGluR}}$ was reduced by $\sim 50 \%$ (wt, $5.83 \pm 0.82 ;$ stg, $2.88 \pm 0.59 ; n=8$ and 8 , respectively; $p<0.02$ ) (Fig. $2 B$ ). The amplitude of the climbing fiber evoked $I_{\text {kainate }}$ was similar ( $n=7$ and 5 for wt and $\left.s t g ; p>0.05\right)$, suggesting that the number of climbing fiber synaptic contacts onto Purkinje cells and the amount of glutamate released was unaffected in stargazer mice. Thus, stargazer Purkinje cells have a severe reduction of synaptic AMPARs, which most likely influences the excitability and firing of these neurons.

In addition to its role in synaptic targeting, stargazin also promotes the plasma membrane trafficking of AMPARs. We assayed extrasynaptic AMPAR expression by applying glutamate to Pur- 

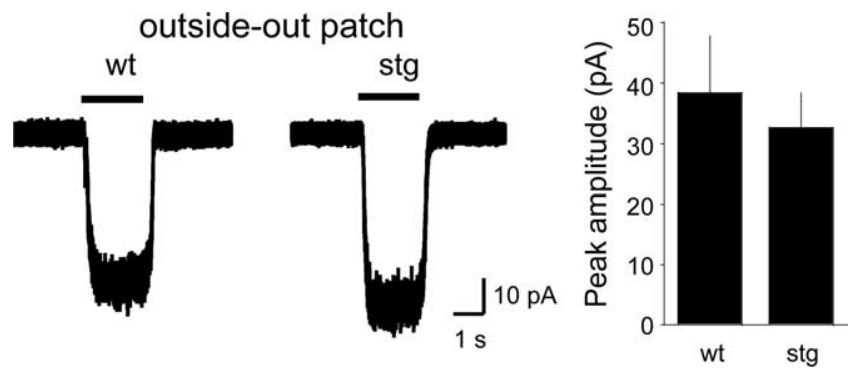

Figure 3. The density of extrasynaptic AMPARs in Purkinje cells is unchanged in stargazer mice. Sample traces of the response to a $2 \mathrm{~s}$ application of glutamate $(10 \mathrm{~mm})$ to outside-out somatic membrane patches pulled from Purkinje cells are shown on the left. The average patch current from stargazer and wild-type mice is shown in the bar graph on the right. No significant difference in the current amplitude was found.

kinje cell somatic patches. Unexpectedly, extrasynaptic AMPAR expression was unchanged (wt, $38.4 \pm 9.2 \mathrm{pA}$; stg, $32.6 \pm 5.7 \mathrm{pA}$; $n=18$ and 17, respectively; $p>0.5$ ) (Fig. 3 ), implying that the reduced evoked EPSC size can be attributed to impaired postsynaptic targeting and not a reduced pool of AMPARs on the cell surface.

\section{Discussion}

Stargazin is an unusual protein because it is proposed to be an auxiliary subunit for both AMPARs (Chen et al., 2000) and calcium channels (Letts et al., 1998). Here, we present data suggesting that the loss of AMPA receptors from inhibitory neurons may contribute to stargazer behavioral phenotypes. We observed a significant partial loss of AMPARs from inhibitory nRT neurons in both young and mature mice, but not from excitatory relay neurons. This suggests a network mechanism by which a loss of AMPARs may generate seizures. Thalamic nRT neurons form reciprocal connections with relay neurons and also receive collateral synapses from corticothalamic fibers. Decreased nRT neuron excitability caused by the loss of AMPARs may limit their participation within the thalamocortical network, and eventually lead to disinhibition and absence-like seizures. Recently, a similar mechanism of disinhibition was proposed to underlie seizures associated with Scn1a mutations (Ogiwara et al., 2007), suggesting that localizing mutated genes to specific neuron populations may further understanding of inherited forms of epilepsy. Furthermore, although the primary defect in stargazer mice is the loss of AMPARs, the severely diminished thalamic mEPSC frequency at some ages suggests that synaptogenesis defects occur as well, and these secondary effects may also contribute to their seizures.

The greater dependence on stargazin in nRT neurons compared with relay neurons most likely results from differing relative expression of TARP subtypes. Such a possibility is indicated by previous studies on three cell types: cerebellar granule cells, cerebellar Golgi cells, and hippocampal pyramidal cells. Granule cells only express stargazin, and thus lose all synaptic AMPARs in stargazer mice. In contrast, Golgi cells, which highly express both stargazin and $\gamma-3$, are unaffected by the loss of either gene alone, but have a nearly complete reduction of AMPARs in the absence of both genes (Menuz et al., 2008). Hippocampal pyramidal cells express extremely high levels of $\gamma-8$, and relatively low levels of stargazin and $\gamma$-3. Mice lacking stargazin and $\gamma$-3 have normal AMPAR function, whereas $\gamma-8$ knock-out mice have a partial reduction of synaptic AMPAR content (Rouach et al., 2005; Menuz et al., 2008). Together, these data suggest that any TARP family member can maintain AMPAR expression if present in sufficient numbers.
Thalamic neurons express multiple TARP family members. In addition to stargazin, $\gamma-3$ and $\gamma-7$ have been detected in the mature thalamus, but their cellular expression pattern has not been described (Fukaya et al., 2005; Kato et al., 2007; Lein et al., 2007). Additionally, $\gamma-4$ is found in the thalamus and may be developmentally downregulated as in other brain regions (Tomita et al., 2003; Fukaya et al., 2005). Supporting this possibility, the decay kinetics of mEPSCs in mature relay neurons were significantly faster than in younger neurons (young, $3.26 \pm 0.21 \mathrm{~ms}$; mature, $2.12 \pm 0.17 \mathrm{~ms} ; n=9$ and 10 , respectively; $p<0.02$ ), as expected given AMPAR currents decay most slowly when associated with $\gamma$-4 (Milstein et al., 2007). In contrast, nRT neuron AMPAR decay kinetics were fast at all ages (young, $1.91 \pm 0.22 \mathrm{~ms}$; mature wt, $1.96 \pm 0.33 \mathrm{~ms} ; n=10$ and 6 , respectively; $p>0.05$ ). Thus, a combination of stargazin, $\gamma-3$, and $\gamma-7$ may be associated with AMPARs in thalamic neurons, with relay neurons additionally expressing $\gamma-4$ earlier in development. If stargazin is the most highly expressed TARP in nRT neurons, then the partial reduction of synaptic AMPARs in stargazer mice parallels the situation in pyramidal cells with $\gamma$-8. In contrast, thalamic relay neurons may more closely resemble Golgi cells, with relatively high and equal levels of TARP expression, thus maintaining sufficient TARP expression in stargazer mice.

Stargazer ataxia can also be attributed to a loss of synaptic AMPARs. Although it was previously assumed that the nearly complete loss of AMPARs from cerebellar granule cells underlies stargazer ataxia, our data indicate that a profound reduction of AMPAR function also occurs in Purkinje cells at both climbing fiber and parallel fiber synapses. Climbing fiber synaptic dysfunction is likely to affect complex-spiking in Purkinje cells. It is less clear whether the loss of AMPARs at parallel fiber synapses adversely affects Purkinje cell activity given that parallel fibers arise from granule cells. Stargazer granule cells may be inexcitable because of their lack of synaptic AMPARs, although they may receive some excitatory drive through activation of their NR2C (NMDA receptor subunit 2C)-containing NMDA receptors. Given that all information processed in the cerebellar network must ultimately exit through the Purkinje cell, decreased excitability in both excitatory granule cells and inhibitory Purkinje cells most likely contributes to stargazer ataxia.

There are multiple mechanisms by which a loss of stargazin could lead to decreased synaptic AMPAR content, given that stargazin affects the maturation, surface trafficking, and synaptic targeting of AMPARs. The loss of synaptic AMPARs from stargazer Purkinje cells seems to result from impaired synaptic targeting because extrasynaptic AMPAR content was similar to that in wild-type mice. Interestingly, hippocampal pyramidal cells from $\gamma-8$ knock-out mice show the opposite phenotype: a large reduction of extrasynaptic receptor content, but only a small synaptic loss (Rouach et al., 2005). This may indicate that these TARPs have different subcellular functions, with $\gamma-8$ playing a predominant role in membrane trafficking and $\gamma-2$ in synaptic targeting. The subcellular localization of these TARPs in the hippocampus is consistent with this possibility (Inamura et al., 2006). The remaining AMPARs in Purkinje cells may be associated with $\gamma-7$, which more strongly promotes receptor surface trafficking relative to synaptic localization (Kato et al., 2007; Milstein et al., 2007).

\section{References}

Barclay J, Balaguero N, Mione M, Ackerman SL, Letts VA, Brodbeck J, Canti C, Meir A, Page KM, Kusumi K, Perez-Reyes E, Lander ES, Frankel WN, Gardiner RM, Dolphin AC, Rees M (2001) Ducky mouse phenotype of 
epilepsy and ataxia is associated with mutations in the Cacna2d2 gene and decreased calcium channel current in cerebellar Purkinje cells. J Neurosci 21:6095-6104.

Baulac S, Huberfeld G, Gourfinkel-An I, Mitropoulou G, Beranger A, Prud'homme JF, Baulac M, Brice A, Bruzzone R, LeGuern E (2001) First genetic evidence of GABA(A) receptor dysfunction in epilepsy: a mutation in the gamma2-subunit gene. Nat Genet 28:46-48.

Burgess DL, Jones JM, Meisler MH, Noebels JL (1997) Mutation of the $\mathrm{Ca} 2+$ channel beta subunit gene Cchb4 is associated with ataxia and seizures in the lethargic (lh) mouse. Cell 88:385-392.

Chen L, Bao S, Qiao X, Thompson RF (1999) Impaired cerebellar synapse maturation in waggler, a mutant mouse with a disrupted neuronal calcium channel gamma subunit. Proc Natl Acad Sci U S A 96:12132-12137.

Chen L, Chetkovich DM, Petralia RS, Sweeney NT, Kawasaki Y, Wenthold RJ, Bredt DS, Nicoll RA (2000) Stargazin regulates synaptic targeting of AMPA receptors by two distinct mechanisms. Nature 408:936-943.

De Fusco M, Becchetti A, Patrignani A, Annesi G, Gambardella A, Quattrone A, Ballabio A, Wanke E, Casari G (2000) The nicotinic receptor beta 2 subunit is mutant in nocturnal frontal lobe epilepsy. Nat Genet 26:275-276.

Fletcher CF, Lutz CM, O'Sullivan TN, Shaughnessy JD Jr, Hawkes R, Frankel WN, Copeland NG, Jenkins NA (1996) Absence epilepsy in tottering mutant mice is associated with calcium channel defects. Cell 87:607-617.

Fukaya M, Yamazaki M, Sakimura K, Watanabe M (2005) Spatial diversity in gene expression for VDCCgamma subunit family in developing and adult mouse brains. Neurosci Res 53:376-383.

Inamura M, Itakura M, Okamoto $\mathrm{H}$, Hoka S, Mizoguchi A, Fukazawa Y, Shigemoto R, Yamamori S, Takahashi M (2006) Differential localization and regulation of stargazin-like protein, gamma-8 and stargazin in the plasma membrane of hippocampal and cortical neurons. Neurosci Res 55:45-53.

Kato AS, Zhou W, Milstein AD, Knierman MD, Siuda ER, Dotzlaf JE, Yu H, Hale JE, Nisenbaum ES, Nicoll RA, Bredt DS (2007) New transmembrane AMPA receptor regulatory protein isoform, gamma-7, differentially regulates AMPA receptors. J Neurosci 27:4969-4977.

Klugbauer N, Dai S, Specht V, Lacinová L, Marais E, Bohn G, Hofmann F (2000) A family of gamma-like calcium channel subunits. FEBS Lett 470:189-197.

Lein ES, Hawrylycz MJ, Ao N, Ayres M, Bensinger A, Bernard A, Boe AF, Boguski MS, Brockway KS, Byrnes EJ, Chen L, Chen L, Chen TM, Chin MC, Chong J, Crook BE, Czaplinska A, Dang CN, Datta S, Dee NR, et al (2007) Genome-wide atlas of gene expression in the adult mouse brain. Nature 445:168-176.

Letts VA, Felix R, Biddlecome GH, Arikkath J, Mahaffey CL, Valenzuela A, Bartlett FS 2nd, Mori Y, Campbell KP, Frankel WN (1998) The mouse stargazer gene encodes a neuronal $\mathrm{Ca} 2+$-channel gamma subunit. Nat Genet 19:340-347.
McCormick DA, Contreras D (2001) On the cellular and network bases of epileptic seizures. Annu Rev Physiol 63:815-846.

Meng H, Walker N, Su Y, Qiao X (2006) Stargazin mutation impairs cerebellar synaptogenesis, synaptic maturation and synaptic protein distribution. Brain Res 1124:197-207.

Menuz K, O’Brien JL, Karmizadegan S, Bredt DS, Nicoll RA (2008) TARP redundancy is critical for maintaining AMPA receptor function. J Neurosci $28: 8740-8746$.

Milstein AD, Nicoll RA (2008) Regulation of AMPA receptor gating and pharmacology by TARP auxiliary subunits. Trends Pharmacol Sci 29:333-339.

Milstein AD, Zhou W, Karimzadegan S, Bredt DS, Nicoll RA (2007) TARP subtypes differentially and dose-dependently control synaptic AMPA receptor gating. Neuron 55:905-918.

Ogiwara I, Miyamoto H, Morita N, Atapour N, Mazaki E, Inoue I, Takeuchi T, Itohara S, Yanagawa Y, Obata K, Furuichi T, Hensch TK, Yamakawa K (2007) $\mathrm{Na}(\mathrm{v}) 1.1$ localizes to axons of parvalbumin-positive inhibitory interneurons: a circuit basis for epileptic seizures in mice carrying an Scnla gene mutation. J Neurosci 27:5903-5914.

Olsen O, Funke L, Long JF, Fukata M, Kazuta T, Trinidad JC, Moore KA, Misawa H, Welling PA, Burlingame AL, Zhang M, Bredt DS (2007) Renal defects associated with improper polarization of the CRB and DLG polarity complexes in MALS-3 knockout mice. J Cell Biol 179:151-164.

Qiao X, Noebels JL (1993) Developmental analysis of hippocampal mossy fiber outgrowth in a mutant mouse with inherited spike-wave seizures. J Neurosci 13:4622-4635.

Rouach N, Byrd K, Petralia RS, Elias GM, Adesnik H, Tomita S, Karimzadegan S, Kealey C, Bredt DS, Nicoll RA (2005) TARP gamma-8 controls hippocampal AMPA receptor number, distribution and synaptic plasticity. Nat Neurosci 8:1525-1533.

Singh NA, Charlier C, Stauffer D, DuPont BR, Leach RJ, Melis R, Ronen GM, Bjerre I, Quattlebaum T, Murphy JV, McHarg ML, Gagnon D, Rosales TO, Peiffer A, Anderson VE, Leppert M (1998) A novel potassium channel gene, KCNQ2, is mutated in an inherited epilepsy of newborns. Nat Genet 18:25-29.

Tempia F, Miniaci MC, Anchisi D, Strata P (1998) Postsynaptic current mediated by metabotropic glutamate receptors in cerebellar Purkinje cells. J Neurophysiol 80:520-528.

Tomita S, Chen L, Kawasaki Y, Petralia RS, Wenthold RJ, Nicoll RA, Bredt DS (2003) Functional studies and distribution define a family of transmembrane AMPA receptor regulatory proteins. J Cell Biol 161:805-816.

Wallace RH, Wang DW, Singh R, Scheffer IE, George AL Jr, Phillips HA, Saar K, Reis A, Johnson EW, Sutherland GR, Berkovic SF, Mulley JC (1998) Febrile seizures and generalized epilepsy associated with a mutation in the $\mathrm{Na}+$-channel betal subunit gene SCN1B. Nat Genet 19:366-370.

Zhang Y, Mori M, Burgess DL, Noebels JL (2002) Mutations in highvoltage-activated calcium channel genes stimulate low-voltage-activated currents in mouse thalamic relay neurons. J Neurosci 22:6362-6371. 